\title{
A crítica de Nietzsche ao romantismo*
}

\author{
Remedios Ávila Crespo**
}

\begin{abstract}
Resumo: O artigo pretende analisar o modo como Nietzsche entendeu sua própria relação com o romantismo. Não se trata de determinar "mais uma vez" seu parentesco com o romantismo e com um determinado romantismo, mas de repensar desta feita "uma vez mais" o modo como ele o experimenta e o descreve para, por meio disso, tornar maior e melhor nossa consciência de nós mesmos, para entendermos melhor, por meio desse círculo hermenêutico, esta "larga via" que é a compreensão do outro. Tendo em vista esse fim, dividirei este trabalho em três partes: na primeira examinarei "o mal-entendido" que Nietzsche denuncia a propósito da sua primeira obra; na segunda parte considerarei os elementos do sintoma que conduzem Nietzsche a compreender o romantismo como uma "enfermidade"; finalmente, na terceira explorarei através dos escritos de Nietzsche "o caminho em direção à saúde".
\end{abstract}

Palavras-chave: romantismo - tragédia - saúde - doença

\section{Introdução}

Muitas das perguntas que constituem o âmbito do que chamamos filosofia não teriam nenhum sentido se não existisse $o$ tempo. A originalidade de suas formulações e sua própria vigência - muito mais do que os resultados, pois a filosofia é mais uma arte de perguntar do que um compêndio de respostas - depende do fato de que quem formula essas perguntas está (paradoxalmente)

\footnotetext{
* Tradução de Cláudia Franco Souza. Revisão técnica de Scarlett Marton.

*** Professora da Universidade de Granada, Espanha. Endereço Eletrônico: ravila@ugr.es
} 
envolvido neste fluir contínuo que é o tempo. Digo isso porque a questão da qual irei me ocupar a seguir - a crítica de Nietzsche ao romantismo - tem sido considerada por muitos há muito tempo. Porém, voltar a essa questão vale a pena, na medida em que nos permite compreender melhor a nós mesmos, nós que hoje a formulamos.

Com efeito, há muito tempo se considera a relação de Nietzsche com o romantismo. Desde as investigações de Joël, Andler, Baeumler, Langer, Kein, até algumas mais recentes como as de Campioni, Volpi, Safranski, Janz, entre outros, são muitos os pesquisadores da obra de Nietzsche que estiveram atentos às raízes românticas de seu pensamento ${ }^{1}$. Muito recentemente em Espanha se vem publicando importantes estudos sobre essa temática ${ }^{2}$. Como as reflexões que irei expor neste artigo têm como base esses estudos, destacarei alguns aspectos neles contidos que me servirão como ponto de partida ${ }^{3}$.

Em primeiro lugar, o interesse de Nietzsche pelo romantismo

1 Uma relação pormenorizada desses estudos pode ser encontrada em BARRIOS, Manuel. Voluntad de lo trágico. Sevilha: Er, 1993, p. 93ss.

2 Entre esses estudos destacamos o de Manuel Barrios (já citado na nota anterior). Sobre essa mesma temática destacamos também: BARRIOS, Manuel. Narrar el abismo. Ensaios sobre Nietzsche, Hölderlin y la disolución del clasicismo. Valência: Pre-textos, 2001; BURGOS, E. Dioniso en la filosofía del joven Nietzsche. Zaragoza: Universidad De Zaragoza, 1993; DUQUE, F. La estrella errante. Madri: Akal, 1997; LANCEROS, P. La herida trágica. Barcelona: Anthropos, 1997; LLINARES, J. B. "Los escritos de F. Nietzsche sobre R. Wagner". In: NIETZSCHE, F. Escritos sobre Wagner. Madri: Biblioteca Nueva, 2003; RUIZ, E. Nietzsche y la filosofía práctica. La moral aristocrática como búsqueda de la salud. Granada: Universidad de Granada, 2004; SÁNCHEZ MECA, D. El nihilismo. Perspectivas sobre la historia espiritual de Europa. Madri: Síntesis, 2004, assim como Nietzsche. La experiencia dionisíaca del mundo. Madri: Tecnos, 2005; SANTIAGO, L. Arte y poder. Madri: Trotta, 2004; VERMAL, J. L. I. Barcelona: Anthropos, 1987.

3 Não considerarei aqui nem o conceito nem a periodização do romantismo nem a influência que em Nietzsche tem o novo modelo epistemológico que o romantismo propõe, pois tratei desses temas em outra pesquisa, no meu livro: ÁVILA, Remédios. Identidad y tragedia. Barcelona: Crítica, 1996.

$50 \mid$ Cad. Nietzsche, Guarulhos/Porto Seguro, v.36 n.2, p. 49-82, 2015. 
e seu parentesco com ele não é independente do interesse e do parentesco com o Iluminismo. Nietzsche é um romântico na medida em que e por que é também um iluminista. Nesse sentido, o importante estudo de P. Lanceros, La herida trágica ${ }^{4}$, denuncia com razão o erro que, como o autor defende, o hábito converteu em evidência, e que consiste em equiparar modernidade e iluminismo. O romantismo - que não afasta os pressupostos do iluminismo, mas combate tanto o antropocentrismo quanto o otimismo que o acompanha - é ainda algo distinto: a sombra inseparável do iluminismo, seu necessário avesso e sua outra face. De acordo com as palavras de Lanceros: "o romântico não aparece como o outro da modernidade, apenas assume e destaca a modernidade $d o$ outro" . Por discutível que resulte a equiparação entre as luzes do iluminismo e as trevas do romantismo, com essas duas categorias estético-ontológicas que foram o apolíneo e o dionisíaco na primeira obra de Nietzsche, não é uma ousadia assinalar que no princípio o jovem Nietzsche assim as entendeu ${ }^{6}$. Bem como também advertir que o otimismo do "homem teórico" contrasta com um certo pessimismo, o pessimismo da força, do homem trágico. É certo que Nietzsche denunciará mais tarde que as categorias de "otimismo" e "pessimismo" são equívocas, que podem remeter a princípios explicativos contrários e que a única oposição esclarecedora é a que tem lugar entre "instinto degenerativo" e "afirmação suprema". É certo também, como o próprio Nietzsche reconheceu, que em sua primeira fase ele se rendeu aos encantamentos dessa "fada

4 Para maiores informações a esse respeito, cf. LANCEROS, P. La herida trágica. Barcelona: Anthropos, 1997, p. 59ss.

5 Lanceiros, 1997, p. 72.

6 A esse respeito, cf. MARÍ, A. El entusiasmo y la quietud. Antología del romanticismo alemán, Prólogo. Barcelona: Tusquets, 1979; PAZ, A. La revolución romántica. Poéticas, estéticas, ideologías. Madri: Tecnos, 1986, p. 100ss.

Cad. Nietzsche, Guarulhos/Porto Seguro, v.36 n.2, p. 49-82, 2015. | 51 
Crespo A. R.

maligna" que foi o romantismo. Aquelas oposições - otimismopessimismo, iluminismo-romantismo, luz-sombra - que irão se tornando mais complexas na reflexão do Nietzsche maduro, servem em princípio para entender a oposição entre Apolo e Dioniso ${ }^{7}$. Do mesmo modo que uma dessas divindades é incompreensível sem a outra, os movimentos que constituem a modernidade - iluminismo e romantismo - são o direito e o avesso da mesma realidade. Mas assim como o trágico ia para além da antítese criando uma nova e bem-sucedida realidade, também Nietzsche pretendia ir "além" das oposições assinaladas explorando uma nova perspectiva, um novo olhar, um outro mundo. Em todo caso e como em toda oposição, cada uma das partes era imprescindível para a outra. Ser romântico era, de alguma forma, ser (ou ter sido) iluminista.

Assim a reflexão de Nietzsche é aparentada com o romantismo. Mas, em segundo lugar, essa afirmação deve ser muito bem trabalhada. Nietzsche não era um romântico como o foram e, como ele dizia que o eram, Schopenhauer e Wagner, esses dois alemães - "ultra alemães", como logo veremos - que por temperamento e cronologia estavam muito mais próximos do romantismo do que ele $^{8}$. A filiação romântica de Nietzsche deve ser entendida a partir de um determinado romantismo, o primeiro romantismo [Frühromantik], que não é o romantismo que o filósofo alemão ataca e que, segundo alguns estudiosos, lhe serve como "base de operações" para seus ataques ao romantismo tardio [Spätromantik $]^{9}$. Para clarificar o que quero dizer, desejo destacar três pontos correlacionados e complementares a propósito desta

7 Sobre a evolução da interpretação nietzschiana do par Apolo-Dioniso, cf. SANTIAGO, L. Arte y poder, p. 244ss.

8 Cf. o estudo anteriormente citado de J. B. Llinares.

9 Esta é a interessante estratégia de leitura que Manuel Barrios apresenta: a proximidade de Nietzsche do primeiro romantismo é o que o leva a criticar o romantismo tardio.

52 | Cad. Nietzsche, Guarulhos/Porto Seguro, v.36 n.2, p. 49-82, 2015. 
segunda consideração. Por um lado, como advertiu Manuel Barrios, Nietzsche parte de uma tradição romântica, mas foi além dela ${ }^{10}$. Neste sentido, não se pode exagerar, por outro lado, o componente romântico do seu pensamento como têm feito alguns estudiosos, em especial. E. Kurth e K. Joël ${ }^{11}$. E é preciso destacar a originalidade de algumas das suas exposições, por exemplo, sua consideração sobre o dionisíaco, que contradiz importantes teses românticas (Creuzer, Rohde e Bachofen, entre outros). Segundo Nietzsche, o dionisíaco procede de um instinto profundamente helênico e não é algo bárbaro, originário do solo asiático, sobreposto e estranho ao grego $\left(G T / N T\right.$ 1, KSA 1.31s) ${ }^{12}$. Assim, pois, mesmo reconhecendo a presença de elementos românticos na primeira obra de Nietzsche, há nesta também, como apontado antes e como mais à frente se verá com mais detalhes, uma tomada de posição original frente a problemas destacados pelo romantismo. Finalmente, é justo reconhecer que a proximidade de Nietzsche com o romantismo é sobretudo relativa ao primeiro romantismo, a esta jovem geração idealista - Hegel, Hölderlin, Schelling e Schlegel - que dá seus melhores frutos entre os anos finais do século XVIII e os primeiros anos do século XIX ${ }^{13}$.

Nesta linha de estudo Duque defende três teses que devemos levar em conta. Segundo esse autor, Nietzsche luta: (1) contra um romantismo decadente; (2) em nome dos ideais do primeiro romantismo; (3) na defesa da oculta raiz artística da ciência ${ }^{14}$. E entre muitos pontos de coincidência entre Nietzsche e o primeiro

10 Barrios, 1993, p. 124-125.

11 A esse respeito, cf. M Barrios, 1993, p.124ss e L. Santiago, 2004, p. 177 ss.

12 Sobre esse aspecto, cf. Barrios, 1993, p.126s. D. Sánchez Meca, 2005, p. 309 ss.

13 Sobre esse aspecto, parecem-me especialmente relevantes as reflexões de M. Barrios, 2001, p.121ss; D. Sánchez Meca, 2004, p.55ss; F. Duque, 1997, p. 77ss.

14 F. Duque, 1997, p. 80.

Cad. Nietzsche, Guarulhos/Porto Seguro, v.36 n.2, p. 49-82, 2015. 
Crespo A. R.

romantismo, destaca os quatro seguintes: crítica do presente, ironia e jogo, exaltação da Grécia e do valor exemplar da tragédia e a necessidade de uma nova religião ${ }^{15}$.

Estabelecidas as bases sobre a relação geral de Nietzsche com o romantismo, voltemos ao princípio. Lá tínhamos assinalado que, das perguntas que constituem o âmbito da filosofia, a maioria seria irrelevante se não existisse o tempo, ou seja, a perspectiva, o ponto de vista, a singularidade de uma posição. É isso que faz valer a pena considerar uma vez mais o modo como Nietzsche entendeu sua própria relação com o romantismo. Não se trata de determinar "mais uma vez" seu parentesco com o romantismo e com um determinado romantismo, mas de repensar desta feita "uma vez mais" o modo como ele o experimenta e o descreve para, por meio disso, tornar maior e melhor nossa consciência de nós mesmos, para entendermos melhor, por meio desse círculo hermenêutico, esta "larga via" que é a compreensão do outro. Tal é o propósito deste trabalho: dialogar com um clássico. E um clássico é, entre outras coisas, alguém capaz de transformar uma experiência pessoal e aparentemente intransferível em algo universal, patrimônio de todos. A experiência de Nietzsche com o romantismo foi, em princípio e como tantas outras, uma questão profundamente pessoal. Mas o que a coloca muito acima disso é o seguinte: através dessa experiência, Nietzsche conseguiu fazer um diagnóstico do seu tempo e da Europa de seu tempo e conseguiu também nos dizer algo, sobre o que vivemos hoje, o que somos e o que nos cabe esperar.

Tendo em vista esse fim, dividirei este trabalho em três partes: na primeira examinarei "o mal-entendido" que Nietzsche denuncia a propósito da sua primeira obra; na segunda parte

15 F. Duque, 1997, p. 86.

54| Cad. Nietzsche, Guarulhos/Porto Seguro, v.36 n.2, p. 49-82, 2015. 
considerarei os elementos do sintoma que conduzem Nietzsche a compreender o romantismo como uma "enfermidade"; finalmente, na terceira explorarei através dos escritos de Nietzsche "o caminho em direção à saúde".

\section{O mal-entendido}

Quando em Ecce Homo, essa espécie de "Discurso do método" - que contém uma autobiografia pessoal e intelectual do autor em questão -, Nietzsche reflete sobre o significado da sua primeira obra, ele a qualifica mais de uma vez como um "malentendido". E mesmo o título dessa primeira obra havia sido estranhamente modificado em seu tempo: "Encontrei esse escrito várias vezes citado como 'o re-nascimento da tragédia no espírito da música", escreve Nietzsche $(E H / E H, O$ Nascimento da tragédia 1, KSA 6.307) ${ }^{16}$, lamentando-se, em seguida, de que essa sua obra houvesse sido entendida somente em relação a Wagner, de que só tivessem "tido ouvidos para perceber ali uma nova fórmula da arte, do propósito da tarefa de Wagner." Certamente o "Prefácio para Richard Wagner" que precedia o escrito apenas dava lugar a dúvidas sobre o estreito vínculo da obra com o músico alemão e sobre a expressa vontade de Nietzsche de que assim fosse. Mas, dezessete anos depois de sua publicação, quando a vida havia trocado a amizade por distância e estranheza, Nietzsche reconhece o equívoco e lamenta aquela confusão da sua própria identidade:

Um psicólogo poderia ainda acrescentar por aqueles anos da mocidade na música wagneriana simplesmente nada tem que ver com Wagner; que, se descrevi a música dionisíaca, descrevi aquilo que eu ouvira (EH/EH, O Nascimento da tragédia 4, KSA 6.313).

16 Tradução de Rubens Rodrigues Torres Filhos (doravante RRTF).

Cad. Nietzsche, Guarulhos/Porto Seguro, v.36 n.2, p. 49-82, 2015. 
Crespo A. R.

Mas para o mal-entendido do livro, não é só Wagner que contribui, mas também o "odor" que ele exala. E nesse ponto Nietzsche se refere a Schopenhauer e especialmente a Hegel ${ }^{17}$. Ainda que "em algumas fórmulas está impregnado do fúnebre perfume de Schopenhauer", em geral "cheira chocantemente a hegelianismo" (EH/EH, O Nascimento da tragédia 1, KSA 6.310, tradução de RRTF), ao interpretar metafisicamente uma ideia - a antítese entre o apolíneo e o dionisíaco - compreendendo a própria historia como seu desenvolvimento e fazendo da tragédia a síntese superadora daquela oposição.

A presença de Wagner, Schopenhauer e Hegel constituiu um peso para aquela primeira obra e explica em boa medida o mal-entendido. Para entendê-la adequadamente era necessário que tivesse um título "menos ambíguo". Talvez "Helenismo e Pessimismo" tivesse resumido melhor a importante tese que há nesse escrito: a razão por que os gregos não foram pessimistas, como acabaram com o pessimismo e como praticamente o superaram. Em todo caso, Nietzsche faz um balanço das duas inovações fundamentais de sua obra da juventude: a psicologia do dionisíaco - a afirmação trágica desta vida, inclusive seus problemas mais estranhos e difíceis - e a compreensão do socratismo como um fenômeno propriamente decadente, como um "instrumento da dissolução grega" (EH/EH, O Nascimento da tragédia 1, KSA 6.310). Essas duas inovações permitem ao livro avançar muito além desse outro mal-entendido, a oposição entre otimismo e pessimismo - essa "lamentável charlatanice própria dos tolos" -, desmascarar a simplicidade dessa oposição e reconhecer, numa singular "revolução copernicana", a autêntica antítese: aquela que

17 Uma interessante aproximação entre Hegel e Nietzsche encontramos na obra de F. Duque, F. 1997 , p. 77 , p. 78 , p. 95 e p. 112.

$56 \mid$ Cad. Nietzsche, Guarulhos/Porto Seguro, v.36 n.2, p. 49-82, 2015. 
existe entre o "instinto degenerado" e a "suprema afirmação" (( $\underline{E H} /$ $\underline{E H}$, O Nascimento da tragédia 1, KSA 6.311, tradução de RRTF). Acima de tudo, o jovem Nietzsche colocou nesse livro um importante problema, que serve de fio condutor em toda a sua obra: para que serve a arte? Qual o sentido da arte? Como a arte se relaciona com outras atividades vitais, como por exemplo a ciência e a moral? Essa foi a questão que Nietzsche abordou em seu primeiro livro.

\section{1 - Um problema "seriamente alemão"}

O leitor familiarizado com a obra de Nietzsche e com as características com as quais ele define o "espírito da gravidade" - "sério, grave, profundo, solene" ( $\mathrm{Za} / \mathrm{ZA}$, Do ler e escrever, KSA 6.49) - não se deixará assombrar ao encontrar seis vezes a palavra "seriedade" [Ernst] nesse breve "Prefácio para Richard Wagner" que ocupa pouco mais de uma página. Por outro lado, o jovem catedrático de vinte e tantos anos reivindica para si e para sua obra uma "seriedade" não isenta de ironia. Nesse "Prefácio" em que dedica seu livro ao amigo, que também considera "um predecessor", Nietzsche destaca o fato de que sua obra foi concebida "em meio aos horrores e sublimidades de uma guerra que acabara de começar", ao mesmo tempo em que Wagner preparava seu "escrito comemorativo sobre Beethoven". Esse aparente e enganoso contraste entre "excitação patriótica" e "dissipação estética" entre "seriedade valente" e "jogo jovial" é somente isso, pura aparência. Isso porque num e noutro caso, partir de posições apenas aparentemente contrárias, ambos estavam a cargo de "um problema seriamente alemão", um problema que se situava "com toda propriedade no centro das esperanças alemãs, como vértice e ponto de inflexão". Um problema estético levado tão a sério que faz da arte não um "acessório adicionado à seriedade da existência", 
Crespo A. R.

mas sim "a tarefa suprema e a atividade propriamente metafísica desta vida". Trata-se pois, de considerar a dimensão metafísica da arte e a própria estética como metafísica.

É conhecida a estratégia de Nietzsche para abordar e resolver o problema. Mas dela tratarei brevemente, apenas para mostrar nela a presença e a superação dos elementos românticos. Nietzsche começa (GT/NT 1, KSA 1.25 e ss) reconhecendo nas forças opostas do apolíneo e do dionisíaco - o sonho e a embriaguez - potências artísticas que brotam da própria natureza, forças que a tragédia ática mostra como aparentadas entre si, mas que primeiramente são os extremos de uma antítese. Se o primeiro representa a ordem, a beleza, o equilíbrio, a luz e a vigência do principium individuationis (principio de individuação); o segundo sugere o espanto, o êxtase, a embriaguez e a sombra e a superação daquele princípio. Se Apolo evoca o véu de Maia e mostra que as artes são o que torna a vida possível e digna de ser vivida; Dioniso aponta para o Uno primordial e mostra que o ser humano é mais do que um artista, é ele mesmo uma obra de arte "para supremo deleite do Uno primordial". Em todo caso, Nietzsche adverte que apesar de se tratar do extremo de uma antítese - o apolíneo, como qualquer extremo de uma relação de contrários, não pode ser entendido, nem existir sem seu outro: o dionisíaco. Esta rivalidade, que explica a história inteira da Grécia como o relato dessa alternância entre o apolíneo e o dionisíaco e essa mútua dependência só podem ser explicadas no pressuposto de que, como apontamos anteriormente, o dionisíaco não pode ser entendido como algo estranho e alheio à alma grega, mas sim como algo que a constitui tão profunda e radicalmente como a tendência apolínea a que ela se opõe. Nietzsche distingue aqui muito bem entre o dionisíaco grego e o bárbaro e reconhece "o abismo enorme que separa os gregos dionisíacos e os bárbaros dionisíacos":

$58 \mid$ Cad. Nietzsche, Guarulhos/Porto Seguro, v.36 n.2, p. 49-82, 2015. 
em comparação com aqueles sacerdotes babilônicos e sua regressão do ser humano ao tigre e ao macaco, as orgias dionisíacas dos gregos têm o significado de festividades de redenção do mundo e de dias de transfiguração ${ }^{18}$.

"Redenção" e "transfiguração": essas duas palavras apontam não somente para o significado especial do dionisíaco, como também para a tarefa fundamental da arte. E isto também se aplica à arte apolínea do sonho. Mas a rivalidade entre aquelas forças opostas não teria chamado tanto a atenção de Nietzsche se não houvesse levado já na história do povo grego a uma milagrosa aliança na tragédia de Ésquilo e Sófocles. E esta aliança não teria sido possível sem as duas forças - o apolíneo e o dionisíaco -, se cada um à sua maneira não respondesse a um impulso comum.

Apolo e os deuses do Olimpo representam, frente à amarga sabedoria de Sileno, deus dos bosques, um duelo, uma luta de morte entre a beleza e o horror.

O mesmo impulso que chama a arte para a vida, como a contemplação e perfeição da existência que induz a continuar a viver, fez também surgir o mundo olímpico, que a "vontade" helênica mantinha diante de si como um espelho transfigurador (GT/NT 3, KSA 1.36, tradução de RRTF).

Apolo responde, assim, à mesma necessidade de transfiguração e redenção, apontada a propósito do dionisíaco. Essa necessidade se materializou num "mundo intermediário" [Mittelwelt] que os gregos tiveram que criar para poder viver (GT/NT 3, KSA 1.36). O êxtase dionisíaco constituía, também, uma espécie de "mundo intermediário", só que a resposta a esse êxtase era o contrário da medida recomendada por Apolo. O convite para ultrapassar

18 M. Barrios, 1993, p. 124-125.

Cad. Nietzsche, Guarulhos/Porto Seguro, v.36 n.2, p. 49-82, 2015. 
Crespo A. R.

os limites individuais se opunha à recomendação apolínea de permanecer dentro deles. E, no entanto, aquele descomedimento teria a mesma origem: um velado substrato de sofrimento e de conhecimento, a dolorosa sabedoria de Sileno.

Assim se entende que Nietzsche reconheça - de um modo próximo ao romantismo, que estabelece uma relação direta entre arte e enfermidade - uma relação também diretamente proporcional entre o talento para o sofrimento e o talento artístico. Mas, já muito distante do romantismo, a harmônica unidade do ser humano com a natureza, "vista com tanta nostalgia pelo homem moderno", nada tem a ver a seu juízo com o "ingênuo", entendido como um estado "simples, que resulta por si mesmo, como que inevitável". A beleza harmônica do mundo apolíneo supõe sempre uma vitória "sobre uma pavorosa profundeza" (GT/NT 3, KSA 1.37, tradução de RRTF).

E assim se entende também que a arte por excelência, a tragédia, como toda arte, ofereça um "mundo intermediário" que redime e transfigura o mundo da realidade cotidiana - mas, como arte suprema, confira a esse mundo intermediário um sentido especial. Diante da negação budista da vontade, que se apresenta como um perigo para o homem que desperta do êxtase dionisíaco, nesse "supremo perigo da vontade", que torna o homem dionisíaco supreendentemente próximo de Hamlet e compreensivo quanto ao destino de Ofélia - dele se aproxima a arte "como um mago que salva e cura". Uma arte especial, porém, que diante de um perigo extremo, oferece também uma solução extrema. E oferece também um "mundo intermediário", um véu transfigurador, mas este véu que é mais leve do que a beleza, protege ao mesmo tempo da verdade. O sublime e o ridículo são, como a bela aparência, um velamento da verdade, um encobrimento "mais transparente do que a beleza", que aponta para a verossimilhança. Por isso, diz

$60 \mid$ Cad. Nietzsche, Guarulhos/Porto Seguro, v.36 n.2, p. 49-82, 2015. 
Nietzsche que "o ator teatral vai além da beleza e, no entanto, não busca a verdade" (DW/VD 3, KSA 1.568).

E assim, através deste "mundo intermediário" [Mittelwelt] que parece ser o denominador comum de toda representação artística, retornemos àquele problema "seriamente alemão" [ernshaft deustchen] e concluamos: para que a arte? Em que consiste sua dimensão metafísica? Qual é o significado da arte? A resposta de Nietzsche é inequívoca: enquanto "atividade metafísica", a arte oferece uma resposta à pergunta pelo sentido da existência, oferece uma direção para a experiência da dor, experiência muitas vezes sentida como absurda. É preciso reconhecer aqui a virtus curativa da arte, seu valor para a vida: a arte é consolo, remédio, transfiguração ${ }^{19}$. E a arte trágica, a suprema arte, é também "a arte do consolo metafísico" [die Kunst des metaphysischen Trostes] (GT/ NT 18, KSA 1.119). Por outro lado, consequentemente, Nietzsche sublinha o fato de que a nossa mais alta significação reside em sermos, muito mais do que artistas, obras de $\operatorname{arte}^{20}$. E assim essa obra faz da arte a suprema experiência desta vida - e da estética a máxima expressão da metafísica.

\subsection{Um livro impossível}

"Consolo" e "justificação metafísica": assim se expressava o jovem Nietzsche, que, do ponto de vista da maturidade do

19 Sobre a consideração da arte como consolo, cf. E. Burgos, 2001, p. 91-100.

20 "Somos imagens e projeções artísticas e temos a nossa suprema dignidade no nosso significado de obras de arte - pois só como fenômeno estético o mundo e a existência podem justificar-se eternamente (...) É somente na medida em que o gênio, no ato da procriação artística, se funde com o artista primordial do mundo, que ele sabe algo a respeito da perene essência da arte; pois naquele estado assemelha-se, milagrosamente, à estranha imagem do conto de fadas, que é capaz de revirar os olhos e contemplar-se a si mesma; agora ele é ao mesmo tempo sujeito e objeto, ao mesmo tempo poeta, ator e espectador" (GT/NT 5, KSA 1.47s).

Cad. Nietzsche, Guarulhos/Porto Seguro, v.36 n.2, p. 49-82, 2015. 
Crespo A. R.

Zaratustra, será considerado ainda um "transmundano". Mas é no balanço que faz da sua primeira obra - com o "Ensaio de autocrítica" publicado em 1886 - que aponta as tensões internas que fazem dessa obra, segundo seu autor "um livro impossível".

Nas primeiras páginas desse ensaio, em conexão com essa interrogação de "primeira ordem" e "profundamente pessoal" que segundo Nietzsche, está na base desse livro -, se reconhece um dos seus êxitos indiscutíveis. Nietzsche se pergunta por que os gregos, precisamente os gregos, a "espécie mais bem-sucedida dos homens existente até o momento", tiveram necessidade da tragédia, do horrível e monstruoso que mostra a tragédia. E diante da propagada convicção de que a força acompanha sempre o otimismo e a debilidade o pessimismo, propõe o seguinte: não poderia também ocorrer o contrário? Não poderia existir um pessimismo da força e um otimismo que esconderia uma debilidade constitutiva? (GT/NT, Ensaio de autocrítica 5, KSA 1.12s). Se assim fosse, as categorias "otimismo" e "pessimismo" não poderiam ser definitivas, mas remeteriam a algo mais profundo do qual seriam instrumentos e fenômenos complexos. Por outro lado, em segundo lugar, Nietzsche reconhece também a intenção fundamental que essa obra antecipa outra de suas conquistas: "Ver a ciência a partir da ótica do artista e a arte a partir da ótica da vida" (GT/NT, Ensaio de autocrítica 5, KSA 1.14). Voltarei a tratar mais adiante dessa temática, cuja importância não cabe de modo algum minimizar, mas convém assinalar a sua vinculação com a anterior e como uma e outra reflexão levam a considerar que não é a arte - a estética o referencial e o critério definitivo, mas sim a vida - e de alguma forma, a fisiologia - que oferece um critério inequívoco e último para julgar o valor das coisas (e em última instância os próprios valores). Cabe entender aqui o problema abordado no quarto parágrafo desse "Ensaio de autocrítica", quando Nietzsche, depois de interpretar o

62 Cad. Nietzsche, Guarulhos/Porto Seguro, v.36 n.2, p. 49-82, 2015. 
desejo de beleza nos gregos como resultado da "carência, privação, melancolia e dor", sustenta que o desejo contrário, o desejo do feio, procede da "superabundância, da plenitude, da alegria e do prazer". E Nietzsche defende também que esse instinto é anterior. E nesse ponto podemos contemplar a terceira conquista deste livro: a de haver penetrado agudamente, psicologicamente, no significado do fenômeno dionisíaco e do fenômeno oposto, o moral, entendendo por moral o cristianismo. Mas essas conquistas se opõem a graves deficiências. Já o segundo parágrafo previne contra suas contradições: as "inovações psicológicas e o "valor juvenil" se destacam junto a uma "juvenil melancolia" e uma espécie de "tempestade e ímpeto" [Sturn und Drang] que o fazem adoecer de todos os defeitos de uma "primeira obra", no mau sentido da expressão. Assim Nietzsche explica tanto a compreensão e a indulgência como o desagrado e a estranheza que nele despertam a sua obra de juventude.

A desconfiança romântica que aparece somente no princípio é acusada novamente um pouco depois ${ }^{21}$. Uma vez mais o terceiro parágrafo reconhece ser um "livro impossível":

trata-se de um livro mal escrito, pesado, penoso, frenético de imagens e confuso por causa delas, sentimental aqui e ali, açucarado até o feminino, desigual no tempo (GT/NT, Ensaio de autocrítica 3, KSA 1.14).

E os últimos parágrafos acusam diretamente o verdadeiro responsável pelo desastre, o envenenador que torna impossível uma boa travessia: o romantismo. $\mathrm{O}$ sexto parágrafo aponta para o constrangimento de ter-se servido de uma linguagem imprópria, de ter dito com termos e conceitos emprestados o que de nenhuma

21 Sobre a influência do romantismo na obra de Nietzsche, cf. meu livro: R. Ávila, 1996, p. 73ss.

Cad. Nietzsche, Guarulhos/Porto Seguro, v.36 n.2, p. 49-82, 2015. 
Crespo A. R.

maneira se poderia captar com fórmulas antigas e banais, de haverse confundido com outros, de não ter sabido encontrar sua própria identidade. Quem sabe seja este, mais do que qualquer outro, o erro - e o pecado - da juventude.

As antigas fórmulas (kantianas e schopenhauerianas) eram incapazes de resolver sem corromper a novidade apontada nos novos problemas e perguntas que a obra continha. Sem falar em Wagner e na música alemã; a celebração de ambas significava perder de vista aquilo de que ali se tratava. A música alemã e Wagner com ela, "era romantismo dos pés a cabeça e a menos grega de todas as formas possíveis de arte: ademais, uma destroçadora de nervos de primeira classe, duplamente perigosa (...) em sua dupla condição de narcótico que embriaga e por vezes obnubila" (GT/NT, Ensaio de autocrítica 6, KSA 1.19). Com isso Nietzsche colocara o dedo na chaga de uma grande ferida, a que se produz por causa do conflito aberto entre o romântico e o dionisíaco.

Mas a crítica culmina no último parágrafo do "Ensaio de autocrítica", quando Nietzsche assume a acusação do romantismo que qualquer um poderia dirigir contra a obra. Essa obra é romântica pelo "ódio profundo contra 'o tempo de agora', contra a 'realidade' e contra 'as ideias modernas". Porque prefere não crer em nada mais do que no "agora". Porque deixa ouvir "um baixo contínuo de cólera e de prazer destrutivo, uma raivosa resolução contra tudo que é 'agora', uma vontade que não está demasiado longe do niilismo prático". Porque faz sua "a genuína e verdadeira profissão de fé dos românticos de 1830, sob a máscara do pessimismo de 1850, atrás da qual se prenuncia o usual finale dos românticos, quebra, afundamento, retorno e prosternação, ante uma velha de fé, ante o velho deus". Em suma, essa obra nietzschiana é romântica porque já aponta de que maneira o cristianismo corresponde ao pessimismo. A favor dessa tese, Nietzsche contribui com uma das

64 Cad. Nietzsche, Guarulhos/Porto Seguro, v.36 n.2, p. 49-82, 2015. 
passagens mais controversos: aquela em que aponta o valor da arte como "consolo metafísico" e, portanto, transmundano.

Sobretudo esses dois elementos, haver entendido mal a música e a filosofia alemãs, o fato de colocar esperanças onde nada havia que esperar, e ter assinalado o valor da arte como um consolo metafísico, colocando novamente esperanças onde nada havia que esperar, explicam a distância de Nietzsche em relação à sua primeira obra. Colocam-nos, além disso, no caminho adequado para entender o juízo de Nietzsche sobre o romantismo como um fenômeno também complexo, mas como uma enfermidade que afeta a Europa de muitas e diversas maneiras (por exemplo, não afeta da mesma forma a França e A Alemanha) e a respeito da qual Nietzsche leva a cabo sua experiência pessoal de convalescença e saúde.

\section{A enfermidade}

Esta obra de juventude que surgiu, segundo o autor, na sombra do cansaço, pessimismo e melancolia da velhice, não podia ser outra coisa senão uma obra estranha, difícil e até certo ponto frustrada: "que livro tão impossível teve que surgir de uma tarefa tão contrária à juventude" (GT/NT, Ensaio de autocrítica 2, KSA 1.13). Além do mais, um livro, segundo adverte Nietzsche, que não só havia "posto a perder o grandioso problema grego", como também o problema de "ser alemão".

E isto numa época em que o espírito alemão, não fazia ainda muito tempo teve vontade de dominar a Europa, a força de guiar a Europa, acabava de apresentar sua abdicação definitiva e irrevogável" (GT/NT, Ensaio de autocrítica 2, KSA 1.20).

Assim se expressa Nietzsche a respeito da Alemanha no "Ensaio" de 1886, como se o romantismo e as ideias modernas de 
Crespo A. R.

que tratou fossem responsáveis por entender mal a um só tempo o duplo problema grego e alemão.

\subsection{O romantismo e a enfermidade na Europa}

Existem poucas referências ao romantismo nos anos que se seguiram à publicação de $O$ Nascimento da Tragédia, acumulandose a grande maioria delas na segunda metade da década dos anos oitenta. Mas, um pouco antes disso, em torno dos primeiros anos dessa década, quando escreveu a Gaia Ciência, há algumas importantes referências ao romantismo. No parágrafo 380 dessa obra, Nietzsche parece explicar esse silêncio devido a uma necessidade: a necessidade que tem "o viajante" de se afastar daquilo que quer julgar, de encontrar uma perspectiva adequada, "de fora e por cima" daquilo que constitui o objeto de reflexão. Isso vale especialmente para a Europa, para a reflexão sobre a realidade europeia e para o romantismo que a caracterizava ${ }^{22}$.

Mas o que é o romantismo? Qual é a perspectiva de Nietzsche para poder falar com justiça, quer dizer, sem préjuízos, sobre o romantismo? Também nessa mesma obra, a Gaia Ciência, encontramos uma resposta complexa para um problema complexo, como é o caso do problema romântico. O parágrafo 370 trata diretamente desse problema. Ali Nietzsche faz um novo balanço dos juízos da sua juventude, juízos que adoecem de "erros, exageros e falsas esperanças" e contêm um triplo equívoco: ter interpretado mal o pessimismo do século XIX, como sintoma de um pensamento superior ao do século XVIII, “à época de Kant, Hume,

22 E para poder entender a própria época, é necessário "superar em si mesmo esse tempo e, consequentemente, não só seu tempo, mas também a má vontade e contradição que ele próprio teve até agora contra esse tempo, seu sofrimento com esse tempo, sua extemporaneidade, seu romantismo..." (FW/GC 380, KSA 3.633, tradução de RRTF).

$66 \mid$ Cad. Nietzsche, Guarulhos/Porto Seguro, v.36 n.2, p. 49-82, 2015. 
Condillac e dos sensualistas", haver suposto que o conhecimento trágico era um luxo permitido nessa época e ter entendido a música alemã como expressão de uma força dionisíaca largamente contida. "Vê-se - adverte Nietzsche - que eu desconhecia então o que dava o verdadeiro caráter tanto ao pessimismo quanto à música: o romantismo".

E uma vez mais: o que é o romantismo? Para explicá-lo, Nietzsche começa reconhecendo que arte e filosofia correspondem, cada qual à sua maneira, a uma mesma vontade - são "remédios e alívios" a favor de uma vida que luta por se afirmar. E supõem sempre dor e sofrimento. Porém, existem dois tipos de sofrimento: um que procede de uma vida rica, que oferece a visão trágica da arte dionisíaca; outro que procede de um empobrecimento vital, de uma debilidade constitutiva e reclama para a filosofia e para a arte "calma, silêncio e um mar aprazível" e "embriaguez, convulsão, confusão e loucura." A filosofia de Schopenhauer e a música de Wagner correspondem a essa dupla necessidade de calma e de loucura $^{23}$. Enquanto o homem dionisíaco mostra sua preferência pelo inquietante e pelo terrível como um luxo que pode se permitir, o fraco tem necessidade de doçura, amenidade e bondade. Assim ensina Nietzsche a ver a obra, o acontecimento e o ideal como "sintomas" que mostram a natureza do criador, do autor e de quem tem necessidade de tal empenho. E convida os seus leitores a aplicar esse critério aos valores estéticos: é a falta ou a abundância que lhes deu origem? Essa pergunta convida agora a ir além da estética e instalar-se no âmbito de uma certa "fisiologia"; aponta já para o estilo de um genealogista e poderia ser equivalente a outra: é o desejo de firmeza e de ser o que dá origem a um valor ou, pelo

23 Uma consideração mais detalhada dessa questão se encontra em meu livro: R. Ávila, 1996, p. 222 ss.

Cad. Nietzsche, Guarulhos/Porto Seguro, v.36 n.2, p. 49-82, 2015. | 67 
Crespo A. R.

contrário, é o desejo de inovação e de vir-a-ser? Mas Nietzsche adverte que essa pergunta - como a oposição entre otimismo e pessimismo - não pode ser última e definitiva, porque não carece de ambiguidade, pois o "desejo de vir-a-ser" pode ser sintomático tanto da força como da debilidade. E o "desejo de firmeza, de eternidade, de ser" pode ser sintomático tanto do amor e da gratidão quanto do ódio e da vingança. Este último é o caso, segundo Nietzsche, do pessimismo romântico, que se encontra no fundo da filosofia da vontade de Schopenhauer e na música alemã de Wagner. Diante de tal pessimismo, Nietzsche pressente que se poderia opor um "pessimismo clássico". Como "clássico", porém, lhe parece um termo gasto, propõe a expressão "pessimismo dionisíaco".

Esse é o modo pelo qual Nietzsche entende o romantismo. Mas estamos ainda longe de conhecer sua origem, estabelecer seu valor, ou melhor, de saber quem dele se serve e para quê. $\mathrm{O}$ romantismo é também um fenômeno complexo que não produz os mesmos efeitos quando floresce em solos distintos. Por ora, vejamos como, segundo Nietzsche, o romantismo afeta a Europa.

O parágrafo 24 da Gaia Ciência oferece uma interessante reflexão a esse respeito. Nietzsche distingue nesse livro dois tipos de descontentes: uns, fracos de natureza feminina que fazem a vida mais bela e profunda; outros, fortes, viris que aperfeiçoam e asseguram a vida. A Europa, a velha Europa, assemelha-se com os primeiros, com os que se contentam com "um pouco de embriaguez e entusiasmo", que padecem de um descontentamento crônico e, portanto, impossível de satisfazer, que animam "os que sabem proporcionar consolos que são como opiáceos e narcóticos", que preferem o "pastor" ao médico. Contudo, Nietzsche reconhece que a evolução da Europa não seria possível sem "esse descontentamento e sem esse romantismo enfermo". A velha, enferma e incurável Europa "terminou gerando uma irritabilidade intelectual que 
equivale quase ao gênio e, certamente, à mãe de todo o gênio". Mas, se o romantismo explica o caráter e a evolução da Europa, o movimento romântico não floresceu da mesma maneira em todas as partes. É essa diferença que faz de Wagner um caso espetacular e único, que merece ser tratado à parte.

\subsection{Wagner e o romantismo}

Recordemos novamente nosso ponto de partida nesse segundo momento do texto: o reconhecimento por parte de Nietzsche de que "não havia muito tempo o espírito alemão tinha vontade de dominar a Europa, a força para guiar a Europa". Nietzsche se refere aos últimos anos do século XVIII e aos primeiros do XIX, quando a política, a arte e a filosofia alemãs prenunciavam um futuro carregado de esperança - esperança que logo seria substituída por decepção. Goethe, escreve Nietzsche, "o último alemão por quem tenho respeito" (GD/CI, O que devo aos antigos 5, KSA 6.229s), simbolizava em sua pessoa tudo o que o século XIX se esforçou para conseguir e não conseguiu. Seria possível dizer que em certo sentido o século XIX se esforçou para caminhar em direção a tudo aquilo que Goethe se esforçou para alcançar pessoalmente (...). Como explicar que o resultado global não é um Goethe mas um caos, um suspiro niilista, um não saber onde ir, um instinto de cansaço, que in praxi convida continuamente a regressar ao século XVIII? (sob a forma, por exemplo, de romantismo de sentimento, de altruísmo, de hiper-sentimentalismo, de feminismo no gosto, de socialismo na política). Não será o século XIX ao terminar nada mais do que um século XVIII reforçado, tornado grosseiro, isto é, um século de décadence?"

Mas não é apenas isso; Goethe representou também para a Alemanha a possibilidade de dominar e guiar a Europa. Como 
Crespo A. R.

na idade de ouro também havia representado o mesmo Frederico, o Grande, esse grande exemplo de ceticismo aliado com a força - "esse espírito fatalista, irônico, mefistotélico", como o definiu Michelet. Nessa época,

graças ao indomável, forte e tenaz caráter viril dos grandes filólogos e críticos da história alemães (...) se estabeleceu pouco a pouco, apesar de todo o romantismo da música e da filosofia, um novo conceito de espírito alemão, no qual se destacava decisivamente a tendência ao ceticismo viril (JGB/BM 209, KSA 5.141)

Mas esse "novo conceito de espírito alemão" acabaria por fracassar, pervertendo-se no final pelo romantismo.

A filosofia e a música alemãs acabaram impondo o mesmo espírito a que haviam previamente sucumbido. No que tange à primeira, Nietzsche descreve, no parágrafo 11 de Para além do bem e do mal, a "divertida tolice alemã" que acabou rendida e pervertida pela "fada malvada" do romantismo, naquele tempo "inocente, rico, ainda juvenil do espírito alemão", naquele tempo quando "ainda não se sabia evitar de confundir 'achar' [finden] e 'inventar' [erfinden]!" Um tempo que é contudo para Nietzsche juventude e adoece dos defeitos da juventude; um tempo, ele adverte, que "por mais ousadamente que se disfarçasse em conceitos cinzentos e senis, não se pode fazer maior do que tomá-lo a sério e mesmo tratá-lo, talvez, com indignação moral" (JGB/BM 11, KSA 5.25, tradução de RRTF).

No que tange à música, Nietzsche lamenta a perda "dos bons velhos tempos" que se foram com Mozart e marcam o declínio e a queda da Alemanha e de sua possibilidade de se converter em guia espiritual da Europa (JGB/BM 245, KSA 5.187). Mozart representa o "acorde final de um grande gosto europeu"; enquanto tal, é um acontecimento supra-alemão muito acima dessa forma de

$70 \mid$ Cad. Nietzsche, Guarulhos/Porto Seguro, v.36 n.2, p. 49-82, 2015. 
provincianismo que é o nacionalismo. Por outro lado, Beethoven simboliza o "acorde final de uma transição estilística". Sobre sua música se espraia a mesma luz crepuscular na qual a Europa estava banhada com Rousseau, Schiller, Shelley, Byron; também ele foi um acontecimento supranacional e europeu. Por isso, a música alemã que veio depois, enquanto expressiva somente da alma alemã, só podia ser decadente. Weber, Marschner, até certo ponto Wagner, Schumann... Sobretudo Schumann. Tudo isso nada mais era do que romantismo, um romantismo que não expressava nada acima de si mesmo e havia se tornado pequeno: Schumann - "que levava tudo tão a sério e desde o princípio foi levado também tão a sério" - "na música já não foi nada além do que um acontecimento alemão e não europeu, como foi Beethoven, como foi em maior medida Mozart com Schumann a música alemã correu o perigo máximo de perder a voz para expressar a alma da Europa e rebaixar-se a ser mera patriotada" (JGB/BM 245, KSA 5.187s). Também Wagner até certo ponto. "Até certo ponto" não quer dizer sempre e necessariamente, ainda que sim no final. Wagner ocupa um lugar à parte nesse vir-aser do romantismo, um lugar que merece ser destacado, ainda que apenas brevemente.

Aquilo que analisamos até esse momento mostra até que ponto Nietzsche considerava o nacionalismo um acontecimento retrógrado. Nacionalismo e patriotismo, é nesse ponto que Nietzsche encontra a deficiência da Alemanha do seu tempo e que descreve como algo que ocorre em etapas de debilidade e senilidade. Napoleão, Goethe, Beethoven, Stendhal, Heine e Schopenhauer foram também patriotas, mas em suas velhices. E assim ocorreu com Wagner. O parágrafo 256 de Para além do bem do mal é rico nessas considerações e compõe junto com o texto Nietzsche contra Wagner, intitulado "A que lugar Wagner pertence", um documento de singular relevância para entender a importância da posição 
Crespo A. R.

de Nietzsche diante do seu antigo amigo. Wagner foi também um acontecimento europeu, supra-alemão, e o foi na medida em que sua música expressou o verdadeiro movimento europeu do momento: o tardio romantismo francês dos anos quarenta. Wagner estava para a música assim como Delacroix para a pintura ${ }^{24}$. Aí se mostra a Europa, "a única Europa, cuja alma, aspira ir mais além, mais acima através de sua arte multiforme e tumultuada". Wagner tem tudo em comum com esses movimentos, todos eles dominados pela literatura, fanáticos da expressão, descobridores do sublime, do feio, do horrível, tendendo ao sensacionalismo, à sedução e ao barroco, inimigos da lógica e da linha reta, incapazes de um tempo lento, dominados por um certo desequilíbrio e prostrados ante a cruz. Isso era a Europa e era também o que expressava a música de Wagner enquanto portadora das ideias e do sentir não de uma nação e um povo, mas de uma cultura - a cultura europeia, dominada então pela França. Wagner fazia parte desse contexto, do refinamento, da sutileza, do artifício francês, daquela capacidade para as nuances que faltava aos alemães - os alemães carecem de sentido para as nuances, "não têm dedos, têm patas" (NW/NW, A que lugar Wagner pertence, KSA 6.427). Como Schopenhauer, Heine e o próprio Nietzsche, Wagner "foi um acaso entre os alemães", ainda que no final, Wagner acabasse caindo nas garras do patriotismo e do cristianismo. Mas isso não era Sigfried; era Parsifal.

Em todo caso, Wagner foi um romântico, não à maneira alemã e sim à maneira francesa, do modo mais universal com que então se expressou o romantismo. Tudo naqueles homens - franceses ou "alemães afrancesados", em suma, europeus - apontava para mais alto do que apontava qualquer nacionalismo. Tudo naqueles

24 A esse respeito, cf. CAMPIONI, G. Nietzsche y el espíritu latino. Argentina: El cuenco de plata, 2004, p. 147-153.

72 | Cad. Nietzsche, Guarulhos/Porto Seguro, v.36 n.2, p. 49-82, 2015. 
homens anunciava outra coisa que estava por vir, mas que eles apenas assinalavam, insinuavam. Escreve Nietzsche:

Em conjunto, formavam uma espécie de artistas temerariamente aventureira, suntuosamente violenta, de altos voos e altos cumes, que primeiro teve que ensinar ao seu século - o século das massas - o conceito de "artista". Mas enferma (NW/NW, A que lugar Wagner pertence, KSA 6.428).

Percebe-se que Nietzsche interpreta o romantismo a partir de uma perspectiva fisiológica, como vimos acima, como debilidade, como enfermidade. Precisamente por isso seu juízo não é um juízo moral, mas o resultado de uma perspectiva que adota a genealogia como método para "ajustar o olhar". Finalmente - e mais uma vez voltando a essa obra que faz um balanço da sua própria vida, onde se alternam, como devem mesmo se alternar em toda biografia, a profundidade e o humor, Nietzsche reconhece a sua gratidão por Wagner e os motivos de seu distanciamento posterior. Frente "ao alemão", ao provinciano e genuinamente alemão, Wagner foi um acontecimento que superou tudo isso. Nisso consistia sua grandeza.

Deixo barato o resto de minhas relações humanas; por nenhum preço eu cederia, de minha vida, os dias de Tribschen, dias de confiança, da serenidade, dos sublimes acasos - dos instantes profundos... (...) Assim como sou, em meus mais profundos instintos, estrangeiro a tudo o que é alemão, a tal ponto que já a proximidade de um alemão atrasa minha digestão, assim o primeiro contato com Wagner foi também a primeira vez em minha vida em que pude respirar: senti que o venerava como país estrangeiro, como oposto, como o protesto encarnado contra 'todas as virtudes alemãs"” $(E H / E H$, Por que sou tão esperto $5, \mathrm{KSA}$ 6.288 , tradução de RRTF).

Precisamente o fato de haver sido infiel a essa estranheza, "haver sido condescendente com os alemães", é o que Nietzsche 
Crespo A. R.

nunca perdoou em Wagner, ainda que essa estranheza que explica seu parentesco com Delacroix, Berlioz, Baudelaire, consistisse num mesmo "fundo de incurabilidade e de enfermidade".

\section{O caminho em direção à saúde}

Também Nietzsche conhecia a enfermidade e conhecia bem "essa" enfermidade que se desenvolvia com os sintomas do pessimismo e remetia ao romantismo. Havia lutado contra a enfermidade, opondo a ela uma vontade de saúde que chamou de "vontade do trágico". Será esse o último momento de nossa reflexão; para expor nossas ideias a este respeito, convém considerar o lugar que ocupa no pensamento nietzschiano a convalescença, esse estado transitório, o meio do caminho entre a enfermidade e a saúde ${ }^{25}$.

\subsection{As vantagens da enfermidade e a gratidão do convalescente}

Chama a atenção o modo como Nietzsche tira proveito dos difíceis anos de prova, enfermidade e solidão. Como um alquimista capaz de obter o melhor dos materiais menos nobres, assim Nietzsche faz uso dos seus anos mais duros, como uma experiência chave de que é possível tirar consequências e aprender. A enfermidade é para ele um "meio de conhecimento" (MA I/HH I, Prefácio 4, KSA 2.17s), uma experiência reveladora dos próprios limites e da própria identidade; é também uma experiência artística.

Como meio às vezes de restabelecimento e cura, Nietzsche

25 Além de Zaratustra, essa reflexão ganha corpo nesse importante ano de 1886, em que escreve Para além de Bem e Mal e os prefácios às segundas edições dos livros já publicados, constituindo o chamado "período ilustrado" de seu pensamento.

74| Cad. Nietzsche, Guarulhos/Porto Seguro, v.36 n.2, p. 49-82, 2015. 
confessa que precisava acreditar não estar sozinho, "não ser o único a ser assim, o único a ver assim" (MA I/HH I, Prefácio 1, KSA 2.13, tradução de RRTF). A simples suspeita de afinidade e sintonia podia ser um consolo, mas essa suspeita - ou esperança - era muitas vezes seguida de decepção. Então, surgia uma vez mais a experiência da solidão e a necessidade de inventar uma medicina especial para uma enfermidade que não tinha remédio, porque ninguém mais a compartilhava. Também nisso consiste a experiência artística. Precisamente a esse desejo artístico - ou vontade de saúde - pertence a invenção do "espírito livre", "alegre e corajoso", que precede esse outro filosofema nietzschiano: o além-do-homem. Também ele obedece à experiência profunda de solidão que segue ao "grande desapego", a ruptura em relação a tudo o que unia até então: o próprio lar, a segurança de se sentir a salvo na sua própria casa. O horror repentino por tudo o que até então se havia amado: a estranheza e a vontade de voar para fora e longe que pulsa no fundo daquele "antes morrer do que viver aqui", isso constitui a "primeira vitória" e quem sabe também o início dos anos de enfermidade. Em todo caso, pensa Nietzsche, esse é um movimento tão necessário quanto raro, pois "quem sabe, hoje, o que é essa solidão?" (MA I/HH I, Prefácio 3, KSA 2.17, tradução de RRTF).

No entanto, no prefácio à segunda edição do segundo volume de Humano Demasiado Humano, Nietzsche reconhece o caráter absolutamente necessário e inelutável de sua tarefa, ainda que um alto preço seja cobrado para sua realização. Nietzsche assinala que, quando frente a toda evidência, havia preferido desconfiar de si mesmo e adotar o ponto de vista de outros, posicionando-se contra si mesmo e em prol daquilo que o contrariava, se produziu a rebelião do próprio corpo. "Doença é, em todo caso, a resposta, quando queremos duvidar de nossos direitos à nossa tarefa" (MA I/ 
Crespo A. R.

HH I, Prefácio 4, KSA 2.17, tradução de RRTF). Somente quando se tem coragem de assumir a enfermidade é que se começa a saber tudo aquilo que se deixa atrás de si e também a valorizar o que se conquistou. Nietzsche descreve então a gratidão do convalescente (FW/GC, Prefáciol, KSA 3.345s), a alegria de um espírito que resistiu pacientemente a uma terrível e longa pressão e deixou atrás de si "uma dupla tirania": a tirania da dor, que impõe seu ponto de vista, e a tirania do orgulho, que se nega a extrair as consequências que se seguem da dor. Somente então o filósofo assume sua tarefa de médico e a filosofia passa a ter direito a se chamar também "fisiologia", isto é, "genealogia". Agora a arte não tem mais a última palavra, mas sim a vida (assim se consuma pois a tarefa pretendida no Nascimento da Tragédia: ver a ciência com a perspectiva da arte e a arte através da perspectiva da vida). Tratase de ver se é a enfermidade que inspira em última análise uma filosofia ou se é a saúde. Em todo caso, a vida se torna agora um problema mais complexo, mais profundo, mais "interessante".

Para explicar esse último ponto, é preciso examinar o alcance irônico da reflexão nietzschiana sobre a dor. Em primeiro lugar, a dor constitui um ponto de interrogação, uma pergunta inevitável, mas é também uma escada que nos conduz às nossas últimas profundidades. Para chegar até lá, é preciso ter coragem de reconhecer a dor como um instrumento necessário de emancipação. "Somente a grande dor é o último libertador do espírito", escreve Nietzsche $(F W / G C$, Prefácio 3, KSA 3.350, tradução de RRTF). E a liberdade, como toda liberdade, tem o seu preço:

A confiança do viver se foi: a vida mesma se tornou em problema. E que ninguém acredite que alguém, com isso se tornou sombrio! Mesmo o amor à vida é ainda possível - só que se ama diferente. É o amor a uma mulher que nos deixa na dúvida... ( $F W / G C$, Prefácio 3, KSA 3.350).

76| Cad. Nietzsche, Guarulhos/Porto Seguro, v.36 n.2, p. 49-82, 2015. 
Um amor que assume a defesa e o cuidado da vida. Defender a vida contra a dor significa defendê-la dos juízos que fazemos sobre ela quando nos vence o medo, o tédio, a desilusão, o isolamento. Como ensina Nietzsche, "quem sofre não tem ainda nenhum direito ao pessimismo!" (MA I/HH I, Prefácio 5, KSA 2.374, tradução de RRTF). Porém, a que pessimismo? Pois já sabemos que o pessimismo pode ser sintomático de fenômenos distintos e até opostos.

\subsection{O ponto de vista da saúde}

Nietzsche frequentemente faz uso da expressão "deixar para trás". Suas obras são em certa medida, às vezes, monumento, outras, simplesmente um balanço do que foi realizado. Por isso, Nietzsche adverte que "todos os meus escritos [...] devem ser retrodatados" (MA II/HH II, Prefácio 1, KSA 2.370, tradução de RRTF), porque eles têm muitas vezes - por exemplo os escritos sobre Strauss, Schopenhauer, Wagner - uma atmosfera de despedida. Especialmente os escritos sobre Wagner; eles são "uma homenagem e gratidão para com um pedaço de passado meu, para com a mais bela e também a mais perigosa calmaria de minha viagem" (MA II/HH II, Prefácio 1, KSA 2.370, tradução de RRTF). Mas, em tudo aquilo que "se deixa para trás", quanto mais se avança na convalescença, quanto mais nos aproximamos da saúde, mais Nietzsche destaca o pessimismo. A esse respeito, ele adverte que o espírito livre supõe "uma cura profunda contra todo o pessimismo (a gangrena dos velhos idealistas e heróis da mentira, como se sabe)" (MA I/HH I, Prefácio 5, KSA 2.19). Juntamente com o pessimismo se deixa para trás também aquilo a que tantas vezes o pessimismo remete, como remete um sintoma, o romantismo, "essa 
Crespo A. R.

dieta imprudente e transtornos espirituais" $(F W / G C$, "Prefácio" 1 , KSA 3.345s). Só depois incipit tragoedia (FW/GC, "Prefácio" 1, KSA 3.345) o convalescente deixa de suportar a arte grosseira do romantismo e busca um refinamento que o romantismo não é capaz de oferecer. A essa "confusão dos sentidos" que é a desordem romântica, Nietzsche opõe outra arte "maliciosa, ligeira, fluida e divinamente artificial" (FW/GC, "Prefácio" 4, KSA 3.351), uma arte caracterizada pela serenidade, pelo pudor da alegria, pelo culto à superfície, que como nos gregos não estava oposta à profundidade.

Por isso, quando o pessimismo está unido ao romantismo não há nada nele que evoque a força e a saúde. Mas o pessimista que também havia em Nietzsche não tem nenhuma relação com ele; a terapia antirromântica que recomenda é a de "um pessimista, pois, com a boa vontade ao pessimismo - portanto, em todo caso não mais um romântico" (MA I/HH I, Prefácio 2, KSA 2.371, tradução de RRTF). Dessa terapia faz parte a prevenção contra a música romântica; "Cave musicam" na medida em que ela "desenerva, amolece, efemina, seu 'eterno feminino' nos atrai - para baixo" (MA II/HH II, Prefácio 3, KSA 2.373, tradução de RRTF); para baixo, seguramente para trás, para um passado que serve de pretexto para a melancolia ${ }^{26}$. Diante desse movimento, não é de admirar então que Nietzsche aponte para um contra movimento que leva para cima e para adiante, para um futuro que, para além da Alemanha, se refira à Europa ${ }^{27}$. E aquele ontem e este amanhã devem ser concebidos sob a diferença entre um pessimismo romântico e um pessimismo

26 “... me vem cada vez mais a confiança de que meus livros-de-andança, de fato, não estavam designados apenas para mim, como às vezes parecia. Posso eu agora, depois de seis anos de crescente confiança, enviá-los de novo em viagem de ensaio? Posso, em particular, depô-los no coração e ouvidos daqueles que são dotados de um 'passado' e em quem resta espírito bastante para ainda, em espírito, sofrer seu passado?” (MA II/HH II, Prefácio 6, KSA 2.376, tradução de RRTF).

27 "Vós predestinados, vós triunfadores, vós dominadores do tempo, vós os mais sadios, os mais fortes, vós bons europeus!" (MA II/HH II, Prefácio 6, KSA 2.376, tradução de RRTF)

78 Cad. Nietzsche, Guarulhos/Porto Seguro, v.36 n.2, p. 49-82, 2015. 
trágico (que Nietzsche chama também de "vontade do trágico"; cf. MA I/ HH I, Prefácio 7, KSA 2.376). Mas esse último requer um estado de ânimo e um tempo (ritmo) determinados.

Numa reflexão não isenta de ironia, no prefácio da segunda edição de Aurora, Nietzsche reflete sobre a estreita relação entre a Alemanha e o pessimismo. Kant, Lutero e Hegel explicam esta especial idiossincrasia alemã (M/A, Prefácio, 3, KSA 3.14s). Os três são pessimistas. Kant acredita na moral "não porque a demonstrem a natureza e a história, mas sim, porque elas a contradizem continuamente". Esse é também o caso de Lutero, para quem "se a razão pudesse compreender como Deus, que mostra tanta ira e crueldade, pode ser justo e bom, não faria falta a fé". Também Lutero assumia aquele credo quia absurdum est. Nessa mesma linha deve ser entendida a lógica hegeliana, que tanto contribuiu, segundo Nietzsche, para o triunfo alemão sobre a Europa". Para Hegel, a contradição é o motor do mundo. Todas as coisas se contradizem a si mesmas. "Até na lógica", conclui Nietzsche, divertido, "somos pessimistas". Mas, se é esse o caráter alemão, não poderia o pessimismo dar um passo adiante e extrair suas últimas consequências? Não teria ele de reconhecer que detrás de toda a lógica e, em suma, da filosofia, há sempre pré-juízos morais? Não deveria consistir esse "último passo" na autossuperação da moral por moralidade? Aquele que for capaz de levar a cabo tal tarefa, talvez seja o melhor alemão, o mais fiel ao espírito alemão, o verdadeiro pessimista. Mas esse pessimismo, "inimigo dos meiostermos a respeito de tudo o que seja romantismo e patriotada", não carece de força nem de júbilo (M/A Prefácio 4, KSA 3.15s) e se aventura a explorar o terreno inexplorado. Porém, essa é a tarefa de Zaratustra e com ele começa a tragédia.

Essa tarefa precisa de um tempo diferente do que impõe uma “época de trabalho", como a nossa (M/A, Prefácio 5, KSA 3.17). É 
Crespo A. R.

preciso ter paciência contra esse inimigo que é a pressa, próprio de todas as épocas de trabalho e escravidão, onde não há tempo nem lugar para perguntas sobre o porquê e o para quê. Nietzsche faz o maior elogio aos leitores ideais que espera e para quem são dirigidos seus livros. Leitores perfeitos, filólogos perfeitos, que reconhecem a mais alta e a melhor virtude, o tempo que requer todo autêntico compreender: a lentidão. Escreve Nietzsche:

A filologia é uma arte venerável (...) onde nada se consegue se não se aplicar com lentidão. Precisamente por isso, esta é hoje mais necessária do que nunca; precisamente por isso, ela nos seduz e encanta em meio a esta época de trabalho, quer dizer, de precipitação, que se consome para acabar rapidamente com as coisas. Aquela arte (a filologia) não aceita que tudo acabe rapidamente; ela ensina a ler bem, ou seja, lentamente, com profundidade, olhando para trás e para diante, com segundas intenções, deixando as portas abertas, com dedos e olhos delicados... Meus pacientes amigos, este livro deseja apenas leitores e filólogos perfeitos: aprendei a ler-me bem! (M/A, Prefácio 5, KSA 3.17).

\begin{abstract}
This article aims to analyse the manner in which Nietzsche understood his own relation with Romanticism. It is not a question of specifying once more his kinship with Romanticism and with a specific Romanticism, but of rethinking this time, once more, the way he experiences it and describes it in view of making bigger and better our consciousness of ourselves, in order to understand better, by means of our hermeneutical circle, this large way that is the understanding of the other. Bearing this in mind, I will group this paper in three partes: in the first one, I examine the misunderstanding that Nietzsche denounces on the purpose of his first work; in the second part, I regard the elements of the symptom that lead Nietzsche to comprehend Romanticism as an illness; finally, in the third part, through Nietzsches writings I explore his way towards healthy.
\end{abstract}

Keywords: Romanticism - tragedy - healthy - illness

$80 \mid$ Cad. Nietzsche, Guarulhos/Porto Seguro, v.36 n.2, p. 49-82, 2015. 


\section{A crítica de Nietzsche ao romantismo}

\section{referências bibliográficas}

ÁVILA, Remédios. Identidad y tragedia. Barcelona: Crítica, 1996.

BARRIOS, Manuel. Voluntad de lo trágico. Sevilha: Er, 1993.

- Narrar el abismo. Ensaios sobre Nietzsche, Hölderlin y la disolución del clasicismo. Valência: Pre-textos, 2001.

BURGOS, E. Dioniso en la filosofía del joven Nietzsche. Zaragoza: Universidad De Zaragoza, 1993.

CAMPIONI, G. Nietzsche y el espíritu latino. Argentina: El cuenco de plata, 2004.

DUQUE, F. La estrella errante. Madri: Akal, 1997.

LANCEROS, P. La herida trágica. Barcelona: Anthropos, 1997.

LLINARES, J. B. "Los escritos de F. Nietzsche sobre R. Wagner”. In: NIETZSCHE, F. Escritos sobre Wagner. Madri: Biblioteca Nueva, 2003.

MARÍ, A. El entusiasmo y la quietud. Antología del romanticismo alemán, Prólogo. Barcelona: Tusquets, 1979.

NIETZSCHE. Sämtliche Werke - Kritische Studienausgabe (KSA). Berlim: de Gruyter, 1967/1978. 15 volumes.

PAZ, A. La revolución romántica. Poéticas, estéticas, ideologías. Madri: Tecnos, 1986.

RUIZ, E. Nietzsche y la filosofía práctica. La moral aristocrática como búsqueda de la salud. Granada: Universidad de Granada, 2004.

SÁNCHEZ MECA, D. El nihilismo. Perspectivas sobre la historia espiritual de Europa. Madri: Síntesis, 2004.

. Nietzsche. La experiencia dionisíaca del mundo. Madri: Tecnos, 2005.

SANTIAGO, L. Arte y poder. Madri: Trotta, 2004.

VERMAL, J. L. La crítica a la metafísica. Barcelona: Anthropos, 1987.

Artigo recebido para publicação em 18/01/2015.

Artigo aceito para publicação em 15/02/2015.

Cad. Nietzsche, Guarulhos/Porto Seguro, v.36 n.2, p. 49-82, 2015. 
